\title{
Preliminary estimates of the economic implications of addiction in the United Arab Emirates
}

\author{
C.M. Doran ${ }^{7}$
}

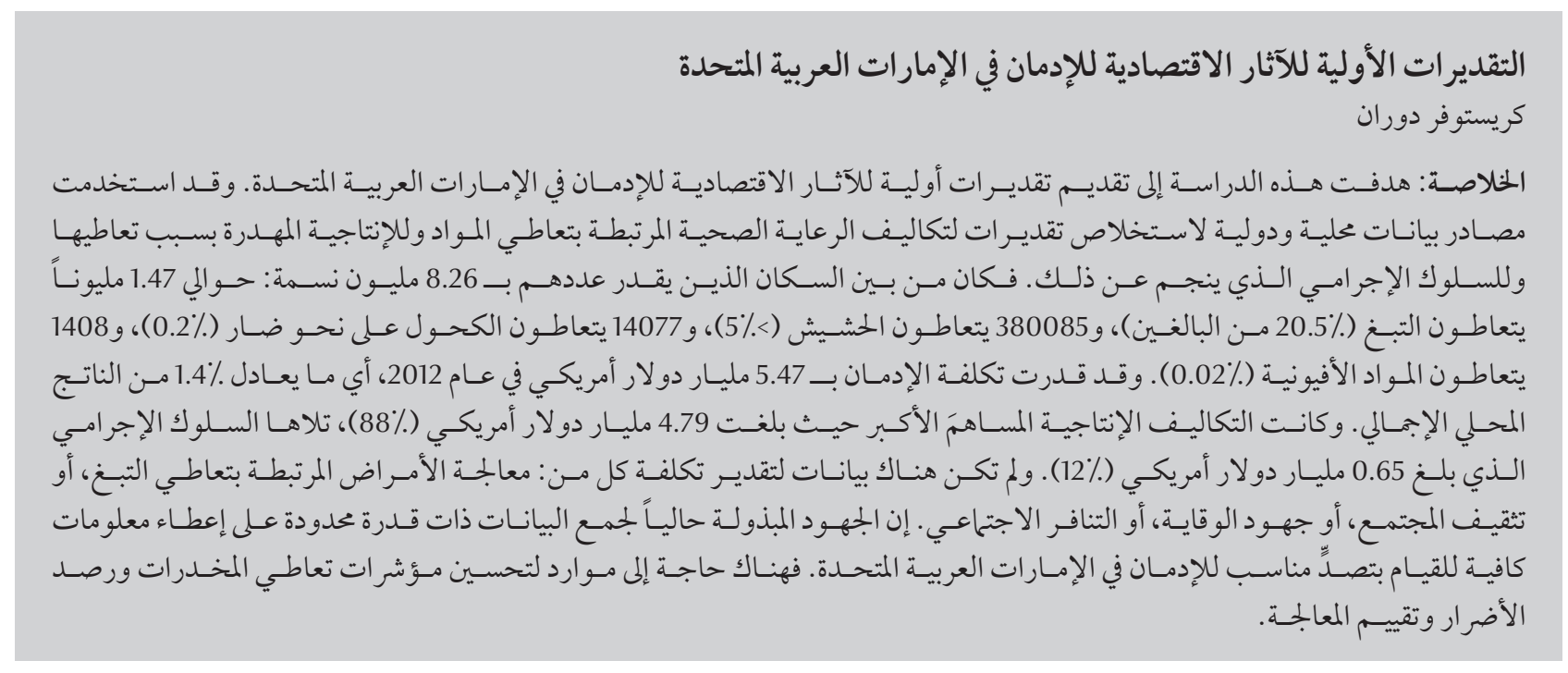

ABSTRACT This study aimed to provide preliminary estimates of the economic implications of addiction in the United Arab Emirates (UAE). Local and international data sources were used to derive estimates of substancerelated healthcare costs, lost productivity and criminal behaviour. From an estimated population of 8.26 million: 1.47 million used tobacco (20.5\% of adults); 380085 used cannabis (> 5\%); 14077 used alcohol in a harmful manner (0.2\%); and 1408 used opiates (0.02\%). The cost of addiction was estimated at US\$5.47 billion in 2012, equivalent to $1.4 \%$ of gross domestic product. Productivity costs were the largest contributor at US\$ 4.79 billion (88\%) followed by criminal behaviour at US\$ 0.65 billion (12\%). There were no data to estimate cost of: treating tobacco-related diseases, community education and prevention efforts, or social disharmony. Current data collection efforts are limited in their capacity to fully inform an appropriate response to addiction in the UAE. Resources are required to improve indicators of drug use, monitor harm and evaluate treatment.

\section{Estimations provisoires des implications économiques des addictions aux Émirats arabes unis}

RÉSUMÉ La présente étude avait pour objectif de fournir des estimations provisoires des implications économiques des addictions aux Émirats arabes unis. Des sources de données locales et internationales ont été utilisées pour produire des estimations sur le coût des soins de santé, la perte de productivité et les comportements criminels liés à la consommation de substances psychoactives. Sur une population estimée de 8,26 millions, 1,47 étaient consommateurs de tabac (20,5\% des adultes), 380085 de cannabis (> $5 \%$ ), 14077 consommaient de I'alcool de façon nocive (0,2\%), et 1408 des opiacés (0,02\%). Le coût des addictions a été estimé à 5,47 milliards de dollars US en 2012, soit 1,4 \% du produit intérieur brut. Les coûts de productivité représentaient le facteur contributif le plus important (4,79 milliards de dollars US, soit $88 \%$ ), suivis par les comportements criminels $(0,65$ milliard de dollars US, soit $12 \%$ ). Aucune donnée n'était disponible pour estimer les coûts induits par le traitement des maladies dues au tabagisme, par l'éducation communautaire et les efforts de prévention, ou par les perturbations d'ordre social. Les efforts déployés actuellement pour collecter des données sont limités du fait de l'incapacité à mettre en place une réponse appropriée aux addictions aux Émirats arabes unis. Des ressources sont requises pour améliorer les indicateurs de la consommation de drogues, opérer un suivi des effets néfastes et déterminer le traitement. 


\section{Introduction}

The use of addictive substances has a wide variety of adverse health and social consequences (1). Substance use affects the ability of individuals to function in a productive capacity; it has negative effects on education and employment; it reduces quality of life and makes people more susceptible to health problems; it affects their self-esteem; and often forces them to engage in criminal behaviour to support their addiction. At the macro level, substance-related crime and corruption affect the Government's ability to address addiction-related harm effectively (2).

Given the economic ramifications of substance use, policy makers are increasingly interested in understanding the economic burden of addiction. Estimates of the economic costs of substance use serve many purposes. First, economic cost estimates are frequently used to argue that policies on alcohol, tobacco and other drugs should be given a high priority on the public policy agenda. Second, economic cost studies help to identify information gaps, research needs and desirable refinements to national statistical reporting systems. Third, improved estimates of the costs of substance abuse offer the potential to provide baseline measures to determine the efficacy of drug policies and programmes intended to reduce the damaging consequences of addictive substances (3).

The United Arab Emirates (UAE) has become a target for the international illicit drug scene due to its strategic geographic location, openness, economic prosperity and young population. Drugs pass through the Middle East, including the UAE, from drug-producing countries in South East Asia, Pakistan and Afghanistan on their way to meeting the high demand of users in drugconsuming countries in Europe and North America (4). The open market trade policy, a fundamental cornerstone of the economy in the UAE, offers a fertile environment for abuses such as illegal immigration, drug trafficking and money laundering (5). Furthermore, the economic and social changes seen in the UAE since 1971 have catapulted people from a nomadic and isolated life into a luxurious lifestyle. To this extent many of the traditional values of the indigenous people have changed and have been influenced by the values and attitudes of those who come to work in the UAE. The rapid social change has been an important factor behind the appearance of many types of antisocial behaviour, of which drug use is one.

The purpose of this study was to provide preliminary estimates of the economic implications of addiction in the UAE

\section{Methods}

As outlined in the international guidelines for estimating the costs of addiction (3), the key types of costs associated with substance abuse include: consequences to the health system (i.e., treatment costs); productivity (i.e., premature mortality or lost employment or productivity); law enforcement and criminal justice; others (such as costs related to prevention and research); and, intangible costs (i.e., social disharmony).

\section{Consequences to the health system}

\section{Healthcare provision in UAE}

The structure of health care in the UAE varies from one Emirate to another. In Abu Dhabi, there are 3 main bodies: the National Rehabilitation Center (NRC), the Health Authority of Abu Dhabi (HAAD) and the Abu Dhabi Health Services Company. In Dubai, there are 2 main bodies: the Dubai Health Authority and the Ministry of Health $(\mathrm{MOH})$. The $\mathrm{MOH}$ is the regulatory and provisional body for public and private healthcare facilities in Sharjah, Ajman, Fujairah, Ras al-Khaimah, Sharjah and Umm al-Quwain (4).

\section{NRC treatment costs}

The NRC is the only specialized addiction centre in the UAE. The first phase of addiction treatment at NRC is detoxification, which can take up to 2 weeks; the second phase is short-term recovery, which lasts for 8 weeks; and the halfway house phase, which takes up to 6 months. The outpatient clinic follows up patients for 1 year after discharge from the halfway house.

A total of 933 patients were admitted to the NRC treatment facility during 2002-2012, with 377 in 2012 (4). Services are provided to local people free of charge. Health statistics from HAAD suggest an average inpatient cost of UAE Dirham (AED) 10861 (US\$ 2957) with an average length of stay of 5.71 days, equivalent to AED 1902 (US\$ 517.93) per day. The cost per outpatient visit is AED 300 (US\$ 81.69). At the NRC, an inpatient stay requires 3 months and an outpatient visit is twice weekly for a further 9 months. Combining this information provides an estimate of NCR treatment costs for local people [i.e., (US\$ 517.93 $\times 12$ weeks $\times 7$ days $\times 377$ patients $)+$ (US\$ $81.69 \times 9$ months $\times 2$ visits per week $\times 377$ patients) ].

\section{Health service cost of treating alcohol and substance abuse}

Statistics on the number of admissions for alcohol and substance abuse are available from HAAD. In 2012, there were 578 admissions with 486 (84\%) originally referred from an outpatient setting $(4,6)$. With an estimated population in Abu Dhabi in 2010 of 2.32 million (6), this equates to an admission rate of 0.249 per 1000 population. Combining this information with UAE population estimates ( 8.26 million) (7), assuming the same rate of service delivery and cost as reported in Abu Dhabi, an estimate can be made of hospital and outpatient alcohol and substance abuse treatment costs for the entire UAE [i.e., (US\$ $517.93 \times 5.71$ days $\times 2292$ patients $)+($ US\$ $81.69 \times$ 1926 patients)]. 
Health service cost of treating tobacco-related diseases

Out of all substances, the evidence relating to tobacco use is perhaps the most advanced with associations between tobacco use and a plethora of diseases well-established (8). In 1994, Lopez et al. suggested a 4-stage model for describing the effects of tobacco smoking on mortality (9) illustrating that smoking-attributed mortality is seen several decades after smoking has occurred. By depicting the epidemic as a continuum spread over many decades, the model allows countries to see themselves as being at a particular stage of an understandable process, spread over a whole century $(9,10)$. With the prevalence of smoking estimated at $>$ $20 \%$ in the adult population (Table 1), the UAE is entering Stage 2 of this model. Given the lag effect between tobacco smoking and disease, deaths from tobacco will inevitably increase. At the time of writing, there was no information available on the treatment costs associated with smoking, therefore no estimate was attempted.

\section{Health service cost of treating prob-} lems related to substance abuse

As well as the direct cost of treating alcohol and substance abuse, there are costs associated with the treatment of side effects and comorbidity. For example, certain users inject drugs into their bloodstream using needles. Sharing needles or using unhygienic needles can lead to HIV infections and other blood-borne diseases (11). Given the lack of data on these possible side effects or comorbidity in the UAE, no attempt was made to quantify these costs.

\section{Cost of substance-related lost productivity}

\section{Impact on quality and quantity of} life

As part of the Global Burden of Disease (GBD) assessment, the Institute for Health Metrics and Evaluation provide disease estimates for the UAE (12). In 2010 for the UAE, drug use, smoking and alcohol use together accounted for almost $10 \%$ of the disease burden, equivalent to 140548 DALYs. (or disability-adjusted life years). A value can be attached to a DALY by using gross domestic product (GDP) per capita. GDP per capita in the UAE was estimated at US\$34 049 (13).

\section{Opportunity cost of time while in treatment}

While patients are in treatment they are not being productive members of society. Productivity costs of treatment can be estimated by: adjusting GDP per capita to a daily rate (US\$ 34 049/48 working weeks/5 working days); combining with the number of admissions to the NRC (i.e., 377 inpatients and 317 outpatients) and the hospitals in the UAE (i.e., 2292 inpatients and 1926 outpatients); and multiplying with average length of stay (i.e., 90 days as NRC inpatient, 5.71 days as hospital inpatient and 1 day per outpatient visit).

\section{Opportunity cost of time while incar- cerated}

When individuals are incarcerated they are often partially or totally removed from the productive economy (3). This constitutes a loss of potential productivity to the economy. This loss is deemed to be justified on the basis of protecting other citizens and punishing offenders, however, it does withdraw a certain number of people from the possibility of participating in productive activities. While acknowledging this as a potential economic cost, this study did not attempt to value the productivity costs of incarcerated drug offenders.

\section{Cost of drug-related criminal behaviour}

In the UAE, law enforcement is the responsibility of each Emirate. Each Emirate's police force is responsible for matters within its own borders, but the forces routinely share information with each other on various issues. The police in the UAE come under the Ministry of Interior and are also responsible for maintaining the prisons, and the arm responsible for this is the Corrections Department (14).

\begin{tabular}{lccc}
\hline Table 1 Estimated prevalence of substance use in the UAE & & \\
\hline Type of substance & $\begin{array}{c}\text { Percentage of population } \\
\text { (aged 15-64) }\end{array}$ & Number of users & Source \\
Alcohol & $0.2 \%$ & 14077 & $(19)$ \\
Amphetamines & No recent data & No estimate & $(17)$ \\
Cannabis & $5.40 \%$ & 380085 & $(17)$ \\
Cocaine & No recent data & No estimate & $(19)$ \\
Ecstasy & No recent data & No estimate & $(17)$ \\
Opioids & $0.02 \%$ & 1408 & $(17)$ \\
Opiates & $0.02 \%$ & 1408 & $(17)$ \\
Prescription opioids & No recent data & No estimate & $(29)$ \\
Tobacco - youth $(<20 \mathrm{yr})$ & $14.0 \%$ & 80248 & $(29)$ \\
Tobacco - adults $(20-64 \mathrm{yr})$ & $20.50 \%$ & 1388163 & \\
\hline
\end{tabular}

$U A E=$ United Arab Emirates; $W H O=$ World Health Organization . 
The main law regulating drug control in the UAE is the Anti-Drug and Substance Use Law (41/4991). Drug use and possession is considered an offence under this law and penalties vary according to the type of substance (15). The legal process of drug-related crimes and offences is organized in three stages: police (arrested and charged within 48 hours), general prosecution (maximum 30 days) and then court. The punishments imposed on guilty persons in drug cases range from putting the person in a treatment centre, a fine, imprisonment (temporary or life) or capital punishment.

\section{Cost of police resources devoted to combating drug problems}

A 2008 United Nations UAE country report suggested that there were: 72 670 recorded crimes; 971 reported drug offences (64 for trafficking); 3688 persons prosecuted; 125 prosecution personnel; 14 adult prisons (with a capacity of 6715); 3295 staff working in the prisons; and, 11193 people incarcerated (16). It is reported that the Dubai Police Force has 15000 officers. Given that Dubai and Abu Dhabi are the two largest Emirates, it may be assumed that the size of the police force in Abu Dhabi may be at least as big as that of Dubai. Therefore, the police force in the UAE is conservatively estimated to be in excess of 30000 .

At the time of writing, there were no data on police resources devoted to combating drug problems in the UAE. However, an Australian report found that $5.9 \%$ of total police activity was spent on combating drug-specific activity (17). To derive an estimate of the police cost associated with combating drug problems in the UAE, the number of police devoted to combating drug problems (using a conservative estimate of $5 \%$ of police time) is multiplied with the average wage of a police officer (using GDP per capita of US\$ 34 049).

\section{Incarceration costs}

According to the prison affiliated focus group discussants in the NRC report (4), prisoners believed that $>10 \%$ of the total prison population were drug abusers. Another data source suggests that the percentage of prisoners who are sentenced for substance abuse ranges from 15 to $20 \%$ (4). Data from the United Nations Office on Drugs and Crime (UNODC) suggest that there may have been 11193 people incarcerated in the 14 adult prisons in the UAE 2008. Applying the same growth rate to the number of incarcerated people as that seen in the population between 2006 and 2012 (i.e., 189\%) (13) suggests that, in 2012, there could have been 21 113 prisoners. If $15 \%$ of this population had been incarcerated for drug offences, this is equivalent to 3170 inmates.

It is costly to employ prison staff and operate a prison. In the absence of any better data, it is assumed that the daily cost of housing an inmate is equivalent to the daily cost of an inpatient stay (i.e., US\$ 517.93) (6). Combining the daily cost with the number of prisoners incarcerated for drug offences (i.e., 3170) suggests a daily cost of US\$ 1.64 million. This cost can be extrapolated to an annual basis by multiplying with 365 days.

\section{Other costs of substance abuse}

There are several other costs to society of substance abuse, including: research on the impact of substance use; public education campaigns to minimize use or abuse; law enforcement programmes to reduce illegal dealing and use; and the cost of social disharmony associated with substance abuse. Development of cost estimates for each of these categories requires extensive data and such information was not available at the time of writing, therefore, no estimates were attempted.

\section{Results}

\section{Population estimates}

The UAE National Bureau of Statistics estimated a population of 8.26 million people in 2010 (7). Non-nationals accounted for $89 \%$ (7.32 million) of the population and nationals for $11 \%$ (0.94 million).

\section{Prevalence of substance use}

There are publically available local data on the prevalence of substance use in the UAE. These rely on data reported in the World Drug Report $(11,18)$. Table 1 provides an estimate of the number of substance users in the UAE. Tobacco use was the most common substance used, with an estimated 1.47 million smokers (20.5\% of adults); 380 085 people ( $5.4 \%$ of the population) used cannabis and an estimated 14077 consumed alcohol in a harmful manner (i.e., $\geq 60$ g pure alcohol on at least one occasion in the past 30 days) (19). To date, there are no accurate estimates on the use, if any, of amphetamines, cocaine, ecstasy, prescription opioids or injecting drugs $(18,20)$.

\section{Preliminary estimates of the economic cost of addiction in the UAE}

The economic cost of addiction in the UAE is estimated at US\$ 5.47 billion; equivalent to $1.4 \%$ of GDP in 2012 (Table 2). Substance-related lost productivity accounted for the majority of costs, $87.6 \%$ of the total or US\$ 4.79 billion, followed by the cost of drug-related criminal behaviour at $11.9 \%$ of total costs or US\$ 0.65 billion.

\section{Discussion}

This study attempted to provide preliminary estimates of the economic implications of addiction in the UAE. For those categories for which estimates were made, several assumptions were 


\begin{tabular}{|c|c|c|}
\hline Category & US\$ & Notes \\
\hline \multicolumn{3}{|l|}{ Consequences to health and welfare system } \\
\hline NRC treatment costs & 16956175 & Based on limited data from NRC \\
\hline $\begin{array}{l}\text { Health service cost of treating alcohol and } \\
\text { substance abuse }\end{array}$ & 6937071 & $\begin{array}{l}\text { Based on limited data from HAAD and } \\
\text { extrapolation to UAE }\end{array}$ \\
\hline $\begin{array}{l}\text { Health service cost of treating tobacco- } \\
\text { related diseases }\end{array}$ & No estimate & $\begin{array}{l}\text { significant given the prevalence of } \\
\text { tobacco use }\end{array}$ \\
\hline $\begin{array}{l}\text { Health service cost of treating problems } \\
\text { related to substance abuse }\end{array}$ & No estimate & No available data \\
\hline \multicolumn{3}{|l|}{ Cost of substance-related lost productivity } \\
\hline Impact on quality of life and longevity & 4785451016 & $\begin{array}{l}\text { Places a dollar value on disability } \\
\text { adjusted life years from global burden }\end{array}$ \\
\hline $\begin{array}{l}\text { Opportunity cost of time while in treatment } \\
\text { for substance abuse }\end{array}$ & 6988807 & $\begin{array}{l}\text { Based on limited data from NRC, } \\
\text { HAAD and extrapolated to UAE }\end{array}$ \\
\hline $\begin{array}{l}\text { Opportunity cost of time while in treatment } \\
\text { for tobacco conditions }\end{array}$ & No estimate & $\begin{array}{l}\text { significant given the prevalence of } \\
\text { tobacco use }\end{array}$ \\
\hline $\begin{array}{l}\text { Opportunity cost of time while in treatment } \\
\text { for substance abuse related problems }\end{array}$ & No estimate & No available data \\
\hline $\begin{array}{l}\text { Opportunity cost of time while incarcerated } \\
\text { for substance abuse offences }\end{array}$ & No estimate & $\begin{array}{l}\text { No available data but likely to be } \\
\text { significant }\end{array}$ \\
\hline \multicolumn{3}{|l|}{ Cost of substance-related criminal behaviour } \\
\hline $\begin{array}{l}\text { Cost of police force devoted to combating } \\
\text { drug problems }\end{array}$ & 51072776 & $\begin{array}{l}\text { Based on limited data }-5 \% \text { of police } \\
\text { force (assumed to be } 30000 \text { ) devoted } \\
\text { to drug control }\end{array}$ \\
\hline Cost of prosecution and operating courts & No estimate & $\begin{array}{l}\text { No available data but likely to be } \\
\text { significant }\end{array}$ \\
\hline Incarceration annual cost & 599274078 & $\begin{array}{l}\text { Based on limited data - } 15 \% \text { inmates } \\
\text { incarcerated for drug offenses, daily } \\
\text { cost of US\$ } 517.93\end{array}$ \\
\hline Salary of prison staff & No estimate & $\begin{array}{l}\text { No available data - partially included } \\
\text { in daily cost of keeping inmates in gaol }\end{array}$ \\
\hline Other police costs in strategic alliances & No estimate & $\begin{array}{l}\text { No available data but likely to be } \\
\text { significant }\end{array}$ \\
\hline \multicolumn{3}{|l|}{ Other costs of substance use } \\
\hline $\begin{array}{l}\text { Cost of community education and } \\
\text { prevention around substance abuse }\end{array}$ & No estimate & $\begin{array}{l}\text { No available data but likely to be } \\
\text { significant }\end{array}$ \\
\hline Education implications & No estimate & $\begin{array}{l}\text { No estimate - likely to be significant } \\
\text { given high drug use among youth }\end{array}$ \\
\hline Employment implications & No estimate & $\begin{array}{l}\text { No estimate - likely to be significant as } \\
\text { school drop-outs increase }\end{array}$ \\
\hline Social disharmony & No estimate & $\begin{array}{l}\text { No estimate - likely to be significant as } \\
\text { increase in crime and violence affects } \\
\text { community sense of security }\end{array}$ \\
\hline Total cost substance use & 5466679923 & \\
\hline GDP (2012) & 383799194081 & \\
\hline$\%$ substance cost/GDP & $1.4 \%$ & \\
\hline
\end{tabular}

$G D P=$ gross domestic product; $H A A D=$ Health Authority of Abu Dhabi; $N R C=$ National Rehabilitation Center; $U A E=$ United Arab Emirates.

required. First, cost data obtained from HAAD were used to derive treatment cost estimates. Treatment at the NRC was intensive, resulting in a high cost for this particular specialist treatment setting. If costs were less expensive in other Emirates compared with Abu Dhabi, derived healthcare costs would be inflated. Conversely, there were no 
estimates of treating tobacco-related diseases or other problems related to substance abuse, which suggests that healthcare costs are generally conservative. Second, most of the cost associated with lost productivity related to substance abuse was derived by combining the current global burden of disease estimates, using the DALY metric, with estimates of economic output per capita. DALY estimates are subject to a high degree of uncertainty due to a lack of local data and the subsequent need for statistical inferences about the UAE compared to other high-income countries (12). Furthermore, the assumption that the per capita income of the whole population in the UAE is applicable to non-locals might skew the estimates towards the higher end of the cost spectrum. Third, due to a lack of data, no estimates were made of costs associated with efforts to educate the population to prevent the uptake of substance abuse.

In spite of the methodological challenges, this analysis has demonstrated that substance abuse is a problem in the UAE with an estimated cost of addiction placed at US $\$ 5.467$ billion, equivalent to $1.4 \%$ of total economic output. This estimate is conservative given that not all costs were quantified.

Despite the apparent importance of costing studies, few researchers have examined the economic impact of addiction. Most efforts to date have considered costs associated with the use and abuse of alcohol, tobacco and illicit drugs (21). Single et al. quantified the economic costs of alcohol, tobacco and illicit drugs to Canadian society at US\$ 18.4 billion, representing US\$ 649 per capita (22). In Australia, Collins and
Lapsley estimated the social costs of alcohol, tobacco and illicit drugs at US\$ 34.4 billion (23). Mark et al. estimated the economic cost of heroin addiction in the United States of America at US\$ 21.9 billion (24). García-Altés estimated the social cost of the consumption of illegal drugs in Spain at US\$ 0.467 billion (25).

Drug addiction is ubiquitous and a significant economic burden on UAE society. Although the data may not be available at the moment to consider the full spectrum of costs, the limited information that is available points to a significant problem that may worsen unless effective solutions are proposed and implemented. In other developed countries, the ways in which governments respond to drug addiction usually represent a blend of options across different government portfolios, including policing and law enforcement, education, community and welfare services and health services. For example, in Australia, one of the aims of the National Drug Strategy is "to achieve a balance between harm-reduction, demand-reduction and supply-reduction measures to reduce the harmful effects of drugs" (26). This approach has been echoed worldwide (11). The National Drugs Policy in Switzerland emphasizes "the four pillar model as a pragmatic middle way", and aims to increase the interchange between prevention, treatment, harm reduction and law enforcement (27). The latest American drug control strategy also emphasizes a balance between prevention, treatment, law enforcement and international cooperation (28). In the UAE, the primary focus to date has been on demand reduction with less attention on treatment and harm reduction. Various government agencies work closely with international entities like the United Nations, Interpol and other countries to stop the activities of drug traffickers. The government has also enacted laws that regulate drug control (4).

\section{Conclusion}

Governments are increasingly relying on evidence to inform policy. The changes in drug use that are being reported in the UAE require a swift and sustained response. Such responses will be best developed using solid evidence that can be collected and disseminated quickly to inform strategic policy responses. Resources need to be devoted to improving the ability to identify, analyse and evaluate indicators of drug use, associated harm and treatment options. Current data collection efforts are limited in their capacity to fully inform appropriate prevention, treatment and/ or harm reduction responses.

\section{Acknowledgements}

The author would like to acknowledge funding received from UNODC and support provided by Dr Asma Fakhri. Staff from the NRC assisted in identification of a range of local reports. Two anonymous reviewers provided constructive comments on how to improve the quality of this manuscript. Any omissions or errors in analysis or interpretation of data rest solely with the author.

\section{Funding: None.}

Competing interests: None declared.

\section{References}

1. Neuroscience of psychoactive substance use and dependence. Geneva: World Health Organization; 2004 (http:// www.who.int/substance_abuse/publications/en/Neuroscience.pdf, accessed 29 September 2016).
2. Doran CM. An analysis of, and proposed methodology for, measuring the socio-economic impact of drugs, crime and corruption in the Lao PDR. Vientiane: United Nations Office of Drugs and Crime Lao PDR Regional Office; 2008. 
3. Single E, Collins D, Easton B, Harwood HJ, Lapsley H, Kopp $\mathrm{P}$, et al. International guidelines for estimating the costs of substance abuse. Geneva: World Health Organization; 2003.

4. Situation assessment of drug abuse in UAE: first phase secondary data collection (2012-2013). Abu Dhabi: National Rehabilitation Center; 2014.

5. Shihab M. Economic development in the UAE. In: Abed I, Hellyer P, editors. United Arab Emirates: a new perspective. London: Trident Press; 2001: 249-59.

6. Health Authority Abu Dhabi. Health statistics 2011. Abu Dhabi: HAAD; 2012 (http://www.haad.ae/HAAD/LinkClick. aspx?fileticket=c-IGoRRszqc=, accessed 29 September 2016).

7. The World Bank. United Arab Emirates. http://data.worldbank.org/country/united-arab-emirates, accessed 29 September 2016 .

8. National Center for Chronic Disease Prevention and Health Promotion (US) Office on Smoking and Health. The health consequences of smoking - 50 years of progress: a report of the Surgeon General. Atlanta: Centers for Disease Control and Prevention; 2014.

9. Lopez AD, Collishaw N, Piha T. A descriptive model of the cigarette epidemic in developed countries. Tob Control. 1994 Sep;3(3):242-7.

10. Thun M, Peto R, Boreham J, Lopez AD. Stages of the cigarette epidemic on entering its second century. Tob Control. 2012;21(2):96-101.

11. United Nations Office on Drugs and Crime. World drug report 2014. New York: United Nations; 2014 (https://www.unodc. org/documents/wdr2014/World_Drug_Report_2014_web. pdf, accessed 29 September 2016).

12. GBD profile: United Arab Emirates. Seattle: Institute for Health Metrics and Evaluation; 2010 (http://www.healthdata.org/ sites/default/files/files/country_profiles/GBD/ihme_gbd_ country_report_united_arab_emirates.pdf, accessed 29 September 2016).

13. World Bank. World Development Indicators. http://data. worldbank.org/data-catalog/world-development-indicators, accessed 29 September 2016.

14. United Arab Emirates Ministry of Interior. Police services. (http://www.moi.gov.ae, accessed 29 September 2016).

15. Ministry of the Interior. Federal Law No. 14 of 1995 on the Countermeasures against Narcotic Drugs and Psychotropic Substances (https://www.unodc.org/res/cld/document/ are/federal-law-no-14-of-1995_html/UAE-fedlaw_14-95.pdf. Accessed 29 September 2016).

16. United Arab Emirates: police 2005-2006. Vienna: United Nations Office on Drugs and Crime; 2008 (https://www.unodc. org/documents/data-and-analysis/United\%20Arab\%20Emirates.pdf, accessed 29 September 2016).

17. Ritter A, McLeod R, Shanahan M. Monograph No. 24: Government drug policy expenditure in Australia - 2009/10. DPMP Monograph Series. Sydney: National Drug and Alcohol Research Centre; 2013 (https://ndarc.med.unsw.edu.au/ sites/default/files/ndarc/resources/24\%20Government\%20 drug\%20policy\%20 expenditure\%20in\%20Australia\%20-\%20 2009_10.pdf, accessed 29 September 2016).

18. World Drug Report 2011. Statistical annex: illicit drug consumption. Vienna: United Nations Office on Drugs and Crime; 2012 (https://www.unodc.org/documents/data-and-analysis/ WDR2011/StatAnnex-consumption.pdf, accessed 29 September 2016)

19. World Health Organisation. WHO Report on alcohol: United Arab Emirates. Geneva: WHO; 2014 (http://www.who.int/ substance_abuse/publications/global_alcohol_report/profiles/are.pdf. Accessed 29 September 2016).

20. United Arab Emirates - Global AIDS response progress report 2012. Country progress report: United Arab Emirates; 2014 (http://files.unaids.org/en/dataanalysis/knowyourresponse/ countryprogressreports/2014countries/ARE_narrative_report_2014.pdf. Accessed 29 September 2016).

21. Doran CM. Economic evaluation of interventions to treat opiate dependence: a review of the evidence. Pharmacoeconomics. 2008;26(5):371-93. PMID:18429655

22. Single E, Robson L, Xie X, Rehm J. The economic costs of alcohol, tobacco and illicit drugs in Canada, 1992. Addiction. 1998 Jul;93(7):991-1006. PMID:9744130

23. Collins DJ, Lapsley HM. Counting the cost: estimates of the social costs of drug abuse in Australia in 1998-9. National drug strategy monograph series no. 49. Canberra: Commonwealth of Australia; 2002 (http://drogfokuszpont.hu/wp-content/ uploads/kokk_social_cost_australia_99.pdf, accessed 29 September 2016).

24. Mark TL, Woody GE, Juday T, Kleber HD. The economic costs of heroin addiction in the United States. Drug Alcohol Depend. 2001 Jan 1;61(2):195-206. PMID:11137285

25. García-Altés A, Ollé JM, Antoñanzas F, Colom J. The social cost of illegal drug consumption in Spain. Addiction. 2002 Sep;97(9):1145-53. PMID:12199830

26. National Drug Strategy 2010-2015: a framework for action on alcohol, tobacco and other drugs. Canberra: Commonwealth of Australia; 2011 (http://www.nationaldrugstrategy.gov.au/ internet/drugstrategy/Publishing.nsf/content/DB4076D49F 13309FCA257854007BAF30/\$File/nds2015.pdf, accessed 29 September 2016).

27. Switzerland's national drugs policy: The federal government's third package of measures to reduce drug-related problems (MaPaDro III) 2006-2011. Bern: Federal Office of Public Health; 2006 (http://www.bag.admin.ch/themen/ drogen/00042/00624/03048/index.html?lang=en, accessed 29 September 2016).

28. Office of National Drug Control Policy. 2010 National Drug Control Strategy (https://www.whitehouse.gov/sites/default/files/ondcp/policy-and-research/ndcs2010_0.pdf, accessed 29 September 2016).

29. WHO report on the global tobacco epidemic: United Arab Emirates. Geneva: World Health Organization; 2015 (http:// www.who.int/tobacco/surveillance/policy/country_profile/ are.pdf?ua=1. Accesses 29 September 2016). 